\title{
Contents, Vol. 51, 1987
}

\section{No. 1 Original Paper}

Cord Blood Levels of Corticotropin-Releasing Factor

Nagashima, K.; Yagi, H.; Yunoki, H.; Noji, T.; Kuroume, T 1

Effect of Metoclopramide Therapy on Arginine Vasopressin Excretion and Renal Water

Handling in Premature Infants

Sulyok, E.; Kovács, L.; Lichardus, B.; Bircak, J 5

Wavelength Dependence of the Geometric and Structural Photoisomerization of Bilirubin

Bound to Human Serum Albumin

Itoh, S.; Onishi, S.; Isobe, K.; Manabe, M.; Yamakawa, T 10

Effect of Insulin on Glucose/Oxygen and Lactate/Oxygen Quotients across the Hindlimb of

Fetal Lambs

Wilkening, R.B.; Molina, R.D.; Battaglia, F.C.; Meschia, G 18

Metabolic Quotients and Oxygen Extraction across the Uterus of the Post-Term Pregnant

Rabbit under Chronic Steady-State Conditions

Jones, R.O.; Murray, R.D.; Meschia, G.; Battaglia, F.C 24

Contribution of Hepatic Fatty Acid Oxidation and Exogenous Galactose Supply to the

Regulation of Glucose Homeostasis in the Newborn Rabbit

Pégorier, J.P.; Duée, P.H.; Girard, J.R

Tin Protoporphyrin Inhibits Carbon Monoxide Production in Suckling Mice

Stevenson, D.K.; Watson, E.M.; Hintz, S.R.; Kim, C.B.; Vreman, H.J 40

Characterization of Lipoprotein Lipase Activity in the Newborn Rat Liver

Reina, M.; Vilaró, S.; Ramirez, I.; Llobera, M

Breast-Milk-Enhanced Intestinal and Somatic Growth in Neonatal Rats

Berseth, C.L 53

Acknowledgement 60

Announcement

No. 2 Experimental Aspects of Normal and Diabetic Pregnancy

Glucose Metabolism in Pregnancy

Leturque, A.; Hauguel, S.; Ferré, P.; Girard, J 64

Lipid Metabolism in Pregnancy

Herrera, E.; Gómez-Coronado, D.; Lasunción, M.A 70

Accelerated Starvation in Pregnancy: Implications for Dietary Treatment of Obesity and

Gestational Diabetes mellitus

Metzger, B.E.; Freinkel, N 78

Maternal Factors Modulating Nutrient Transfer to Fetus

Lasunción, M.A.; Lorenzo, J.; Palacin, M.; Herrera, E 86

Placental Transfer of Non-Esterified Fatty Acids in Normal and Diabetic Pregnancy

Thomas, C.R 94

Placental Function in Maternal-Fetal Fat Transport in Diabetes 
Shafrir, E.; Barash, V 102

IV Contents

Mechanisms of Congenital Malformations in Diabetic Pregnancy

Eriksson, U.J.; Karlsson, M.-G.; Styrud, J 113

Research Priorities in Diabetic Pregnancy Today: The Role of Animal Models

Baird, J.D.; Aerts, L 119

Subject Index 128

No. 3 Original Paper

Pre- and Perinatal Clinical Characteristics of Infants Who Suffer Sudden Infant Death Syndrome

Stebbens, V.A.; Alexander, J.R.; Southall, D.P 129

Measurement of Carbon Dioxide Production Rate in Sick Ventilated Premature Infants

Lucas, A.; Nohria, V.; Roberts, S.B 138

Skinfold Thickness and Adiposity Index in Premature Infants

de Gamarra, M.E.; Schutz, Y.; Catzeflis, C; Freymond, D.; Cauderay, M.; Calame, A.;

Micheli, J.L.; Jéquier, E 144

Elevated Levels of $\mathrm{c}^{1 / 8}$-Macroglobulin-Protease Complexes in Infants

Levine, J.J.; Udall, J.N., Jr.; Evernden, B.A.; Epstein, M.F.; Bloch, K.J 149

Age-Related Development Profiles of the Antioxidative Defense System and the Peroxidative Status of the Pig Heart

Das, D.K.; Flansaas, D.; Engelman, R.M.; Rousou, J.A.; Breyer, R.H.; Jones, R.; Lemeshow, S.; Otani, H 156

Protective Effect of Vitamin E against Lipoperoxides in Developing Rats

Yoshioka, T.; Motoyama, H.; Yamasaki, F.; Ando, M.; Yamasaki, M.; Takehara, Y. . 170

Lipogenesis in the Brown Adipose Tissue of the Fetal Baboon

Chakrabarty, K.; Maeta, H.; Vidyasagar, D.; Jeffay, H.; Manaligod, J.R 177

No. 4 Original Paper

Effects of Oral L-Carnitine Supplementation in Low-Birth-Weight Premature Infants

Maintained on Human Milk

Melegh, B.; Kerner, J.; Sándor, A.; Vincellér, M.; Kispál, G185

Pedigree of the Major Histocompatibility Complex in a Family with a Neonatal Alloim-

mune Thrombocytopenia

Panzer, S.; Kiefel, V.; Mayr, W.R.; Fielder, A.H.L.; Lachmann, D.; Mueller-Eckhardt, C. 194

Plasma Amino Acids in Interrupted Aortic Arch and the Hypoplastic Left Heart

Syndrome

Halliday, H.L.; Moore, R.; O’Hara, D

198

Fetal Arginine Vasopressin under Basal and Hypoosmolal Conditions

Leake, R.D.; Ervin, M.G.; Ross, M.G.; Stegner, H.; Fisher, D.A 204

Net Sodium and Water Movements in the Newborn Rabbit Collecting Tubule: Lack of

Modifications by Indomethacin

Reyes, J.-L.; Roch-Ramel, F.; Besseghir, K 212

Fetal Beta-Endorphin Levels in Response to Reductions in Uterine Blood Flow

Skillman, C.A.; Clark, K.E 217

Enhancement of Lung Conditioning by Acetylcholine in the Prevention of Respiratory

Distress Syndrome in the Preterm Fetal Lamb

Kolobow, T.; Solca, M.; Chen, V.; Buckhold, D.K.; Pierce, J.E 224 
Contents

$\mathrm{V}$

Effect of Guanidinoethyl Sulfonate on Taurine Concentrations and Fetal Growth in Preg nant Rats

Ejiri, K.; Akahori, S.; Kudo, K.; Sekiba, K.; Ubuka, T 234

Announcement 216

No. 5 Original Paper

Hemodynamic and Ventilatory Effects of High-Frequency Jet and Conventional Ventilation in Piglets with Lung Lavage

Suguihara, C; Bancalari, E.; Goldberg, R.N.; Barrios, P.; Hehre, D 241

Vasopressin Functions as an Endogenous Antipyretic in the Newborn

Kasting, N.W.; Wilkinson, M.F 249

Effect of Progesterone on the Testosterone and Estradiol Levels in the Hypothalamus of

Neonatal Rats

Rhoda, J.; Valens, M.; Edwards, D.A.; Roffi, J 255

Developmental Pattern of Ornithine Decarboxylase Activity, S-Adenosylmethionine De-

carboxylase, and Polyamines of Rat Adrenal Glands

Ekker, M.; Sourkes, T.L 260

Role of Catecholamines in the Control of Newborn Kidney Adenine Nucleotide Content

Sofack, F.; Bastin, J.; Boulekbache, FL; Bismuth, J.; Delaval, E.; Geloso, J.P 268

Effects of Perinatal Exposure of Albino Rats to Chloroquine

Mgbodile, M.U.K 273

Adrenalectomy and Pentagastrin Effects on Gastrointestinal Cholinergic Enzyme

Activities

Heitkemper, M.M.; Shaver, J.F 277

Effects of Parenteral and Enteral Nutrition on Postnatal Development of the Small Intestine and

Pancreas in the Rabbit

Gall, D.G.; Chung, M.; O’Loughlin, E.V.; Zahavi, I.; Opleta, K 286

No. 6 Original Paper

Cell Proliferation in Developing Human Jejunum

Arsenault, P.; Ménard, D 297

Decreased Plasma Arachidonic Acid Binding Capacity in Neonates

Sadowitz, P.D.; Walenga, R.W.; Clark, D.; Stuart, M.J 305

A Prospective Study on the Intrauterine Growth of Hong Kong Chinese Babies

Fok, T.F.; Lam, T.K.; Lee, N.; Chow, C.B.; Au Yeung, H.C.L.; Leung, N.K.; Davies, D.P. 312

Heat Production and Respiratory Enzymes in Normal and Runt Newborn Piglets

Hayashi, M.; Ingram, D.L.; Dauncey, M.J 324

Effects of Maternal Caffeine Ingestion on the Perinatal Cerebrum

Tanaka, H.; Nakazawa, K; Arima, M 332

Rat Placentae Gamma-Glutamyltransferase Activity Changes during Pregnancy

Baumrucker, C.R.; Stover, R 340

Reproductive Organs in Anencephaly with Special Reference to the Uterus

Zondek, L.H.; Zondek, T 346

Author Index, Vol. $51 \quad 352$

Subject Index, Vol. $51 \quad 353$ 